University of Louisville

ThinkIR: The University of Louisville's Institutional Repository

Electronic Theses and Dissertations

8-2011

\title{
A social networking space : a study on the productivity of Twitter in museum practice.
}

Cara C. Lyons

University of Louisville

Follow this and additional works at: https://ir.library.louisville.edu/etd

Part of the Fine Arts Commons

\section{Recommended Citation}

Lyons, Cara C., "A social networking space : a study on the productivity of Twitter in museum practice." (2011). Electronic Theses and Dissertations. Paper 870.

https://doi.org/10.18297/etd/870

This Master's Thesis is brought to you for free and open access by ThinkIR: The University of Louisville's Institutional Repository. It has been accepted for inclusion in Electronic Theses and Dissertations by an authorized administrator of ThinkIR: The University of Louisville's Institutional Repository. This title appears here courtesy of the author, who has retained all other copyrights. For more information, please contact thinkir@louisville.edu. 


\title{
A SOCIAL NETWORKING SPACE: A STUDY ON THE PRODUCTIVITY OF TWITTER IN MUSEUM PRACTICE
}

\author{
By \\ Cara C. Lyons \\ B.A., University of Kentucky, 2010

\begin{abstract}
A Thesis
Submitted to the Faculty of the

College of Arts and Sciences of the University of Louisville in Partial Fulfillment of the Requirements

for the Degree of
\end{abstract}

Master of Arts

Department of Fine Arts

University of Louisville

Louisville, Kentucky

August 2011 
Copyright 2011 by Cara C. Lyons

All Rights Reserved 

A SOCIAL NETWORKING SPACE: A STUDY ON THE PRODUCTIVITY OF TWITTER IN MUSEUM PRACTICE

By

Cara Christine Lyons

B.A., University of Kentucky, 2010

A Thesis Approved on

August 2, 2011

By the following Thesis Committee:

John P. Begley

Thesis Director

Peter Morrin

Annette C. Allen 


\section{ACKNOWLEDGMENTS}

Sincere gratitude is hereby extended to my advisor and professor John Begley for his guidance and patience this past year. I would also like to thank the other members of my committee for their support, Annette Allen and Peter Morrin. 


\section{ABSTRACT}

\section{A SOCIAL NETWORKING SPACE: A STUDY ON THE PRODUCTIVITY OF TWITTER IN MUSEUM PRACTICE}

Cara C. Lyons

August $8^{\text {th }}, 2011$

With the evolution of social networks and technological innovations, services such as Twitter provide a platform for increased dialogue and participation. Micro-blogging features enable individuals and organizations to communicate directly, providing a new source of individual commentary that breaks the barriers of traditional communicative paradigms. This research targets museum social networking through close examination of the history of Twitter in museums, as well as its benefits, strategies, and goals in utilizing technology to foster an authentic museum experience. Another aim of this study is to highlight the challenges and obstacles museums face in constructing a social network that positively supports its mission and respective collection. Five local and national museums are examined in addition to an in-depth analysis of the American Museum of Natural History. By expanding traditional modes of participation and effectively utilizing Twitter, each museum delivered differentiated approaches for reaching institutional success in engaging audiences. 


\section{TABLE OF CONTENTS}

\section{PAGE}

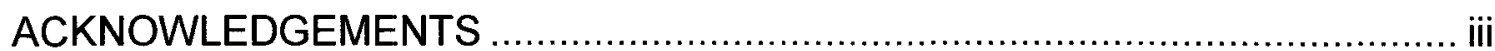

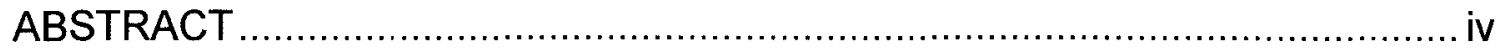

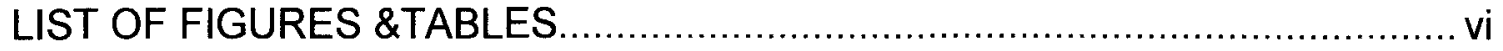

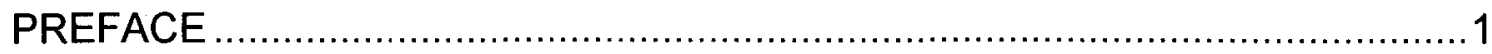

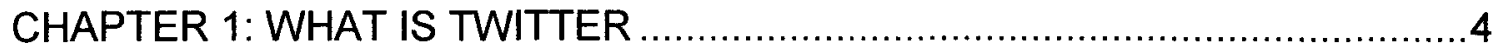

CHAPTER 2: HOW TWITTER IS BEING USED IN MUSEUMS $\ldots \ldots \ldots \ldots \ldots \ldots \ldots \ldots$

CHAPTER 3: BENEFITS OF TWITTER ............................................... 13

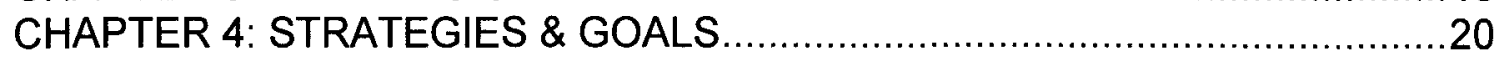

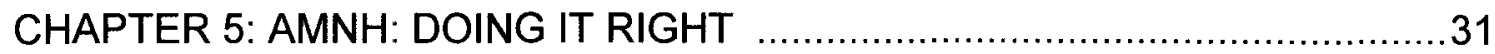

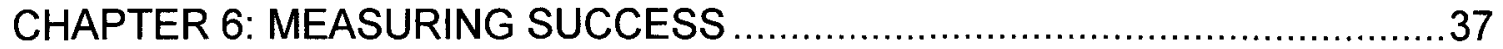

CHAPTER 7: CHALLENGES OF SOCIAL NETWORKS ............................42

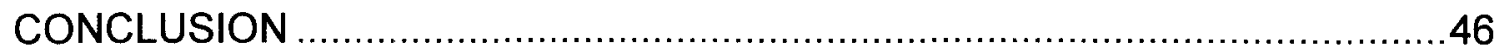

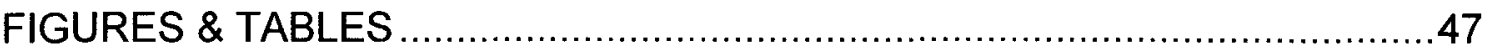

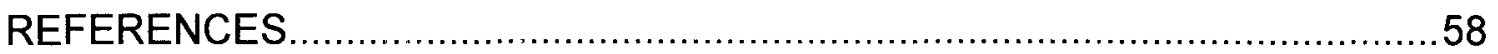

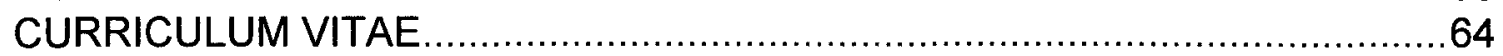




\section{LIST OF FIGURES AND TABLES}

PAGE

FIGURE ONE: AMNH Trends, Retweets, Replies ......................................

FIGURE TWO: Cincinnati Art Museum Educational Outreach Tweets ..............16

FIGURE THREE: Metropolitan Museum of Art Engagement Tweets................18

FIGURE FOUR: Brooklyn Museum Authenticity in Tweets ............................23

FIGURE FIVE: Arts Hotel Poor Example of Linked Tweets ..............................25

FIGURE SIX: Cincinnati Art Museum "Work of the Week" Tweet .....................26

FIGURE SEVEN: New Museum George Condo Tweet ................................27

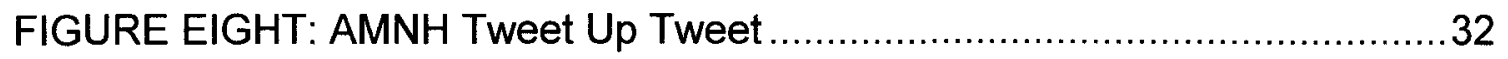

FIGURE NINE: Twitter Website Sample Statistics ....................................... 37

FIGURE TEN: Twitter Counter Sample Statistics........................................40

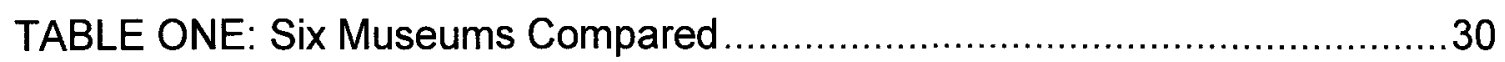




\section{PREFACE}

In today's electronic world the term, "social networks" is used to mean discussions that connect us to one another. The discovery of both old and new friends, commonalities, and disagreements are all products of social networking. To satisfy our current information-hungry generation, networks such as Twitter are providing communities with more than just the basic, who, what, when, where, and why; they are allowing participants the opportunity to connect, evaluate, and offer personal opinion. This research will demonstrate Twitter's ability to provide new methods to communicating with institutions through an innovative forum for interaction.

As a personal account holder, I appreciate the open forum Twitter offers for participation, experimentation, and learning. I engage with museums on Twitter for consistent updates on current events, exhibitions, and collection information, as well as share unique experiences through behind-the-scenes information, such as photos and videos. Through this research I highlight how important consistency in updating is to fueling a positive experience for Twitter users. I chose to address the importance of social networking in museums because it positively stimulated me to engage further and reach out to the museums on Twitter. The informative content and encouraged discussion on 
Twitter educates, excites, and influences me to participate; to seek out additional information online, to visit the museums, and it transforms my visitor experience.

Museums are benefiting from Twitter's opportunities to influence individuals to visit, engage, and learn, just as it did me. By using Twitter, it fuels on-site attendance, activates audiences, and creates new relationships. Twitter is a new resource for advancing communication between audiences and institutions and responds to the shift in social norms of our present generation. By utilizing Twitter as a new method of communication, museums are achieving institutional success by becoming responsive organizations that allow their audiences to quickly, easily, and repeatedly engage with their collections and programs on personal terms.

In this thesis, I will establish the fundamentals of Twitter and provide individual examples of museums utilizing Twitter's advantages productively. The list of examined institutions include the Metropolitan Museum of Art, Brooklyn Museum, Cincinnati Art Museum, 21c Museum/Hotel, New Museum, and the American Natural History Museums. These museums demonstrate that by using new social media methods, they are making a significant impact on their communities.

This thesis explores benefits for institutions that employ Twitter and other social media strategies. Four main advantages highlighted are ease of access, increased exposure, deepened engagement, and expanded educational opportunities. All are evaluated in depth, as well as specific strategies to achieving each advantage. Strategies such as the development of museum 
social networking positions and tweeting etiquette are evaluated. This thesis concludes by comparing varying approaches to measuring the success of a museum's Twitter account. 


\section{CHAPTER ONE}

\section{WHAT IS TWITTER?}

Twitter Inc. launched on March $21^{\text {st }}, 2006$ as an information network. Since its construction, Twitter has joined the ranks of social networking big leaguers, Facebook, Myspace, and Linkedln. This social network provides its users with a free service used for communicating and connecting with users through several different and accessible outlets, including mobile devices and computers. Twitter users can create personal or organizational accounts to reach and inform interested audiences. ${ }^{1}$

Twitter comprises itself of tweets. A tweet is a comment reduced to 140 characters, limiting it from being acknowledged as a blog but rather making it a networking space designed for micro-blogging. Micro-blogging's objective is to deliver the latest news to individuals in a succinct and simple fashion. Users can expand tweets with links to webpages, as well as attach related videos and images. Additionally, users can search organizations, family, friends, co-workers, and celebrities of their choice and add each to a "following" list that is significant for their individual interests. Account holders are able to view composed tweets

\footnotetext{
${ }^{1}$ Paul Gillin, Secrets of Social Media Marketing: How to Use Online Conversations and Customer Communities to Turbo-Charge Your Business (Fresno: Quill Driver Books, 2009), 128.
} 
from their following list through mobile applications, available on their smartphone, or via the Twitter homepage, which provides up-to-date tweets, informing the user constantly. ${ }^{2}$

When following different Twitter accounts, names are identified with an @ sign, for example “@username.” By following @username, users read the tweets composed by that account holder and are encouraged to reply or retweet to engage with the content @ username delivers. To reply, users must include the @ username prefix in their tweet. Twitter recognizes replies and delivers notifications to the account user (@username), which are accessible on the users' home page. If the user chooses to retweet, they may re-post someone else's tweet to their own followers, reaching further Twitter users. Retweeting spreads information to multitudes of personal networks, supporting individual or organizational accounts as their tweets' reach is extended to multiple, new audiences. When topics become popular on Twitter, it is called "trending." To tweet on a trending topic, users use a hash tag before the topic word, for example, \#trendingtopic. Trending topics are viewed on the users homepage to see what fellow users are "buzzing" about. ${ }^{3}$ See page 47 , Figure One, for an example of the American Museum of Natural History's use of trends, links, replying and retweeting.

${ }^{2}$ Juliette Powell, 33 Million People in the Room: How to Create, Influence, and Run a Successful Business with Social Networking (Upper Saddle River: Pearson Education, Inc., 2009), 25.

3 "Frequently Asked Questions," Twitter, accessed May 25, 2011, http://support.twitter.com/entries/13920-frequently-asked-questions. 
When visiting a specific account, such as @ username, the number of users following @username is visible, as well as the number of users @ username has on its personal following list. In addition, the number of tweets composed since registration are shown, indicating how active a user is. This data is useful when evaluating who to follow. While organizations keep accounts public, Twitter users are given the option to create a private account, which means only chosen individuals are allowed to view your tweets. Twitter also offers private messages that work as an internal email system, an additional outlet of communicating and connecting with others interested in a particular topic. $^{4}$

On March 21, 2011, Twitter's fifth anniversary, creators revealed the statistics of their social networks' growth over the past five years. In March 2006, for example, Twitter originated with eight employees and quickly reached four hundred employees by March 2011. It took three years, two months, and one day to reach the one-billionth tweet. Currently, it takes one week to reach a billion tweets. Fifty million tweets were sent in twenty-four hours a year ago and this has now reached 177 million tweets daily. On March 11, 2011, 572,000 new accounts were registered and this number continues to increase daily since. ${ }^{5}$ Twitter is a world wide social network, recognized for the effortlessness use of its system and its immediateness of communication for both personal entertainment and

\footnotetext{
4 "Frequently Asked Questions."

${ }^{5}$ Carolyn Penner, "\#numbers," (blog), TwitterBlog, March 14, 2011, http://blog.twitter.com/2011/03/numbers.html.
} 
organizational development. Twitter answers the question, "What is happening now?" 


\section{CHAPTER TWO}

\section{HOW TWITTER IS BEING USED IN MUSEUMS}

Museum communication functions are rapidly adapting to a generation of technologically savvy individuals that are using Twitter. Presently, museums endeavor to interact with audiences through progressive approaches to communicating. A critical turning point in museum history occurred when institutions began to focus less on collecting the object and more on the function of educating and informing broad audiences about the use and scope of the objects and their cultures. ${ }^{6}$ Communication between institutions and audiences evolved through community outreach programs and expanded educational resources, to create a vision of the museum as a public service that fueled threequarters of the world's museums to establish since $1945 .{ }^{7}$ The museum is now a nexus for social interaction.

Reinventing the Museum: Historical and Contemporary Perspectives on the Paradigm Shift, edited by Gail Anderson, includes an article by Stephen Weil, entitled Rethinking the Museum: An Emerging new Paradigm, which elucidates the transformation toward modern social practice in museums. Weil distinguishes

${ }^{6}$ John Begley \& Peter Morrin, Lecture on museum history, Curatorial Studies, University of Louisville, Kentucky, Fall Semester, 2010.

${ }^{7}$ Stephen Weil, "Rethinking the Museum: An Emerging New Paradigm." In Reinventing the Museum: Historical and Contemporary Perspectives on the Paradigm Shift, ed. Gail Anderson, (Oxford: AltaMira Press, 2004), 74. 
the shift in twentieth and twenty-first century museum practice with the retreat from traditional object-based institutions to reinvented community-driven institutions, stating, "Museums should strive to emulate, not what it owns but what it does, not size or completeness of its collection but its capacity to be of immediate practical aid to the community that supports it." ${ }^{\prime 8}$ Today, museums are challenging traditional practice to an even greater extent by utilizing more open communication, such as Twitter, to educate and engage an even larger audience.

The rise of computers, mobile smart phones, and WI-FI capabilities is encouraging museums to interact with audiences through a multitude of available electronic outlets, including Twitter. The impetus for museums to participate in social networking launched with the establishment of Facebook in $2004 .{ }^{9}$ The introduction of Twitter in 2006 triggered numerous museums to integrate themselves into an expanded emerging trend. ${ }^{10}$ With audiences building online, museums are accommodating demands for a strong social presence outside of just their respective webpages. Edward Alexander and Mary Alexander, Museums in Motion: An Introduction to the History and Functions of Museums, also note the shift in communicative and educational resources in museum history, explaining, "Interpretation encompasses how museums communicate

${ }^{8}$ Ibid., 77.

${ }^{9}$ Gillin, 118-119.

${ }^{10}$ Twitter, "Frequently Asked Questions." Accessed

May 25, 2011. http://support.twitter.com/entries/13920-frequently-askedquestions. 
their messages to the public." ${ }^{11}$ In other words, museum education is evolving past the voice of the docent preaching to a passive audience. Twitter has become a forum of interpretation, as audiences and museums have a collaborative conversation on a variety of subjects, including not just the object, but how and why a museum is using its collection.

By accommodating social norms of our present generation, museums are utilizing Twitter as a resource for integrating technology into an authentic museum experience. Present museums have a social responsibility to advance their outreach and increase their dialogue to create multi-directional communication with its audiences. ${ }^{12}$ Through its innovative methods of engaging and connecting with audiences instantaneously, Twitter has become a significant development, historically, in museum practice. In addition to the museums on Twitter, organizations such as American Association of Museums, New York Times Arts, Art in America magazine, and Ask A Curator are emerging and similarly endeavoring to educate visitors, build attendance online, and expand on current events at corresponding museums, galleries, or arts events.

Ask A Curator is a website and Twitter account (@AskACurator) functioning as a "worldwide question and answer session between museums and the world." ${ }^{13}$ Jim Richardson, founder, encourages Twitter users to ask curators

${ }^{11}$ Edward \& Mary Alexander, Museums In Motion: An Introduction Introduction to the History and Function of Museums. Second ed. (Oxford: AltaMira Press, 2008), 258.

12 Weil, "Rethinking the Museum," 75.

${ }^{13}$ Twitter, "@AskACurator." Accessed June 1, 2011. http://twitter.com/AskACurator 
questions on their museum practices by using the hashtag, \#askacurator at the end of each tweet. In doing so, curators divulge answers to the general public on the inner-workings of museum management. Richardson states, "With Ask $A$ Curator we are, on masse, taking Twitter out of the marketing department and putting it in the hands of curators, and at the same time giving the public the chance to hear about interesting subjects from these passionate individuals," continuing, "My hope is that we'll plant a seed in both the curators and the public, and change their expectations to see this kind of digital interaction as part of how a museum or gallery interacts with the public." ${ }^{14}$ In addition to interacting with curators and actively promoting museum engagement, Ask $A$ Curator provides informative surveys, quizzes, and charts related to the benefits of museum social networking. Ask A Curator recently compiled a comprehensive list of each museum ever to register on Twitter, currently reaching 1,500 and continually growing. ${ }^{15}$

Engaging Art: The Next Great Transformation of America's Cultural Life, edited by Steven Tepper, defines our present generation as "the always on generation," explaining new technology is transforming previous museum engagement practices through its continuous connectivity and increased

\footnotetext{
${ }^{14}$ Jenara Nerenberg, "'Ask a Curator" Makes Museum Twitter Feeds Fun Again." Fast Company. Accessed June 12011. http://www.fastcompany.com/1686047/global-ask-a-curator-event-on-twittertempts-social-media-shy-museum-types.

15 @AskACurator, (2011, April 18). 1500+ museums on Twitter, who have I missed out? http://bit.ly/museumtweets2011[Twitter post]. Retrieved from http://twitter.com/\#!/AskACurator.
} 
interactivity. ${ }^{16}$ The roles of museums are changing as they adapt to emerging trends such as Twitter. It has become crucial to build a social presence that provides new modes of outreach, interaction, and collaboration with audiences. Twitter is causing great changes in museum visitor experience and opening a new chapter in museum practice.

${ }^{16}$ Steven J. Tepper \& Bill Ivey, Engaging Art: The Next Great Transformation of America's Cultural Life (New York: Routledge, 2008), 222. 


\section{CHAPTER THREE}

\section{BENEFITS OF TWITTER IN MUSEUM PRACTICE}

Twitter's functional characteristics are helping museums to effectively build an online presence. Ease, exposure, education, and engagement, are four critical advantages Twitter offers to a museum's social network. Ranging from simplicity to a widened scope of audience, Twitter's benefits are constructive and valuable to both the institution and the individual user. In this chapter I identify why ease, exposure, education, and engagement are key advantages of utilizing Twitter's social network.

\section{Ease}

An easy and unique form of social networking is ideal when building an online community. Twitter's simplicity provides museums with a tool for reaching audiences without time consuming or difficult measures. As a free service, Twitter offers museums the benefit of promoting themselves without accruing additional expenses. Micro-blogging in 140 characters or less requires users to be brief and succinct with their messages, creating a simplified way for providing uncomplicated messages to followers. Such petite messages spark curiosity in followers, possibly resulting in additional museum visits or website views for further information. In addition to its micro-blogging capability, Twitter provides 
ease through accessibility. Whether users choose to utilize mobile devices or computers, Twitter is accessible anywhere $3 G$, high-speed mobile service is extended to and can be employed for both sending and receiving tweets simultaneously. Regardless of location, this real-time,${ }^{17}$ multi-directional communication creates instantaneous dialogue between institutions and individuals or even thousands at the same time. ${ }^{18}$

\section{Exposure}

While it takes commitment of time and staff resources to construct a social network of active followers, Twitter offers benefits to museums seeking to gain exposure and build an online identity. Juliette Powell, 33 Million People in the Room, states that social capital, "followers" and cultural capital, "influence," are what compose a successful social network. ${ }^{19}$ Museums can build social and cultural capital by tweeting information that is of significance to the institution to attract and maintain followers. The opportunity to tweet with links to webpages is a practical approach to building influence, which can also attract financial support through museum visits, memberships, and ultimately donations by building engaged participants.

Twitter also offers increased exposure through retweeting. When a

\footnotetext{
${ }^{17}$ technique for updating, in which the content depicted takes place at present time. Social networks display the time that content reaches individuals, often displaying the seconds that have passed since it first reached the Internet. Real time content inputs at the same rate content would be distributed in real life.

${ }^{18}$ Selma Thomas \& Phyllis Hecht, The Digital Museum: A Think Guide Washington DC: American Association of Museums, 2007), 81.

${ }^{19}$ Powell, 76-85.
} 
museum tweets about an event, for example, a follower can and will hopefully choose to retweet it. In doing so, the museum's tweet will reach everyone who follows the individual who retweeted about the new event. Retweeting is free publicity extended to thousands of individuals, reaching locally and often globally. Individuals are stimulated by friends to follow the museum as a result, building further social capital. According to MuseumNext Blog, in recent survey of 1,000 Twitter users, $39.3 \%$ are currently following one to five museums and $42.1 \%$ of Twitter users range between the ages of $25-34$, which continues to grow as exposure increases. ${ }^{20}$ With growing social and cultural capital, museum visits are apt to occur as individual awareness of the museum improves.

Followers personalize their accounts to receive information from museums of their choice. A museum's list of followers is comparable to a modern day mailing list of interested individuals, but instead providing constant exposure. Museums additionally have the option to place a Twitter widget on their home pages. A widget links to the museum's Twitter account, making it accessible to reach from alternate online platforms, such as museum websites. ${ }^{21}$ Keeping Twitter accessible to everyone from multiple angles additionally increases coverage. The use of widgets and retweeting are a few of the methods Twitter offers for attracting a museum following and building influence.

20 Jim Richardson, "Survey-Museums on Twitter," (blog), Museum Next, May 3 , 2011, accessed June 10, 2011, http://www.museumnext.org/2010/blog/researchmuseums-on-twitter.

${ }^{21}$ Joel Comm, Twitter Power: How to Dominate Your Market One Tweet at a Time. (Hoboken: Wiley \& Sons, Inc., 2009), 187. 


\section{Education}

The MuseumNext Blog, referenced previously, asks the question, "Why do you follow a museum on Twitter?" $98.9 \%$ of surveyors answered, "To learn about exhibitions and events." ${ }^{22}$ Information is the first level of education in museum practice and is critical to building informed and interested audiences. Twitter also is a quick way to inform followers about exhibitions and events. Furthermore, Twitter's user-driven approach enhances learning experiences through a constant flow of information and discussion about objects or events between the institution and its clients.

George Siemens article, Connectivism: A Learning Theory for the Digital Age, 2004, states "When knowledge, however, is needed, but not known, the ability to plug into sources to meet the requirements becomes a vital skill. As knowledge continues to grow and evolve, access to what is needed is more important than what the learner currently possesses.. ${ }^{23}$ Placing a link to a website, survey, or blog in a tweet allows followers to further educate themselves and engage with additional information. See page 48, Figure Two, for an example of the Cincinnati Art Museum successfully using links and replies to educate an audience.

MuseumNext blog, also stated, "The majority of tweets feature links and by linking content on other websites, you can advance your museum's education

${ }^{22}$ Richardson, "Survey-Museums on Twitter."

${ }^{23}$ George Siemens, "Connectivism: A Learning Theory for the Digital Age," September 12, 2004, Accessed June 10, 2011, http://www.elearnspace.org/articles/connectivism.htm. 
aims through the web." ${ }^{24}$ Twitter, furthermore, promotes education through collaborative dialogue, in which users learn as they participate in a network of informal mentorship. Twitter is part of a participatory culture, in which users contribute to social conversations and learn from its discourse. ${ }^{25}$ Museums are developing a learning network on Twitter from which their mission to educate is benefiting directly. By posting informative content and user commentary, Twitter offers museums new opportunities to educate their community.

\section{Engagement}

Twitter's collaborative dialogue amongst users and museums builds relationships as they engage and talk with one another, instead of at one another. Museums embracing non-traditional forms of communication are becoming more responsive to audiences as they encourage individuals to respond and relate their personal experiences back to the museum. The digital and fast-paced environment of Twitter increases museums ability to interact with diverse audiences and improve its operations by listening and engaging with constructive feedback. ${ }^{26}$ Social networking shifts the methods museums use to engage audiences, allowing its visitors to actively shape their experience.

\footnotetext{
${ }^{24} \mathrm{Jim}$ Richarson, "Twitter For Museums," (blog), Museum Next, October 29, 2010, accessed June 10, 2011, http://www.museumnext.org/2010/blog/twitterfor-museums.

${ }^{25}$ Tepper and Ivey, 174.

${ }^{26}$ Lynda Kelly \& Angelina Russo, "From Ladders of Participation to Networks of Participation: Social Media and Museum Audiences." Paper presented at the international conference for culture and heritage on-line, (Montreal, Quebec, Canada, September 12, 2008), 2-3.
} 
Tweeting serves as a platform for followers to encounter a more spontaneous and casual side of museums. By sharing videos and photos on tweets, followers become part of behind-the-scenes museum events, fostering a unique and previously unavailable experience. Talking about a recent international conference on culture and heritage, Lynda Kelly and Angelina Russo, From Ladders of Participation to Networks of Participation: Social Media and Museum Audiences, stated the principles to providing a compelling online experience must, "encourage discovery, interaction, cater for the unexpected, provide many pathways to explore, give a taste for what happens behind-thescenes and provide fun content that is challenging, real, authoritative, meaningful, and encourages questions." ${ }^{27}$ Tweets that engage with an audience on a personal and relatable level create opportunities for discussion. See page 49, Figure Three, for an example of the Metropolitan Museum of Art's techniques to engaging an audience by asking questions and replying to individual inquiries. Online discourse generates feedback, in which museums utilize to enhance their content, further educate, and engage with its audiences. Museums gather insight on what stimulates and confuses individuals and are given the opportunity to find alternate solutions to improving audience satisfaction. Social networking allows museums to discover their faults and counteract negative publicity. ${ }^{28}$

Engaging with followers strengthens social networks and offers opportunities to improve on-site visitor attendance rates. MuseumNext's survey

${ }^{27}$ Kelly \& Russo, 9-10.

${ }^{28}$ Randy Kennedy, "The Met's Plans for Virtual Expansion." The New York Times, February 11, 2011, Section C1. 
asked, "Have you visited the museums you follow on Twitter?" $52 \%$ answered "Yes" and an additional $40 \%$ answered "Some of them.." Museums that employ Twitter successfully influence followers to visit their institution. Agence FrancePresse recently published an article by Marie-Pierre Ferey, Internet Helps Museums Net New Art Lovers, stating, "By engaging with relevant content online it actually can be a driver to encourage people to go and see the real thing -- you can't underestimate the thrill of the original. ${ }^{1130}$ Twitter is a social platform, engaging and stimulating both the unfamiliar and experienced museum-goer to extend their social networking experiences into the physical museum, prompting further attendance and possible financial support.

Museums utilize Twitter's benefits of ease, exposure, education, and engagement to transform visitor experiences, build audiences, increase attendance, and grow as an organization. Since Twitter's introduction in 2006, museums have developed countless methods to grow and retain all of Twitter's advantages. Having established social networking advantages in depth, chapter four highlights the goals and specific strategies museums currently employ to capitalize on Twitter's increasing recognition and use by a large and expanding audience.

${ }^{29}$ Richardson, "Survey-Museums on Twitter."

${ }^{30}$ Marie-Pierre Ferey, "Internet Museums Net New Art Lovers," The Manila Times.net, February 5, 2011, accessed June 10, 2011, http://www.manilatimes.net/tech-times/internet-helps-museums-net-new-artlovers. 


\section{CHAPTER FOUR \\ MUSEUM STRATEGIES \& GOALS OF USING TWITTER}

The simplicity of electronic methods for engaging, educating, and building exposure are emboldening museums to advance their online presence. By constructing a successful social network on Twitter, they harness creative new strategies to reach and engage new audiences. Chapter four highlights specific examples of five museum's individual strategies to keep up with technology by adapting new roles and responsibilities for reaching audiences through social networking.

Museum Basics, by Timothy Ambrose and Crispin Paine states, "Change is required to develop the quality of the museum and its work. ${ }^{.31}$ Cultural changes cause museums to develop innovative practices of informing and engaging audiences, and building support both online and offline. Representing local, national, small, and large institutions, the five chosen museums convey similarities and differences in their approaches to applying Twitter's advantages to their institution. The following five museum's strategies will be reviewed: The Metropolitan Museum of Art, Brooklyn Museum, Cincinnati Art Museum, the New Museum, and 21c Museum/ Hotel.

${ }^{31}$ Timothy Ambrose \& Crispin Paine, Museum Basics, 2 ed., (New York: Routledge, 2006), 274. 
The Metropolitan Museum of Art (@metmuseum)

The Metropolitan Museum of Art's Twitter account has 317,499 followers and continues to build daily. At a national level, the Met is reaching more followers than most museums on Twitter. With its ever-growing online population, museum management is implementing varying strategies for capitalizing on Twitter's popularity. ${ }^{32}$ To further connect with followers, as well as broaden their online presence, the Met is refining staff positions to specialize specifically in social networking.

The New York Times recently published an article on the Metropolitan Museum of Art's technological approach to building visitor engagement, stating, "It is a social science aimed at trying to reach every patron, from the first-timer to the seasoned scholar." ${ }^{33}$ To ensure each patron is reached, the Met recently established a social networking and digital-media department. With the internet generation building, it is common for museums to develop occupations solely dedicated to maintaining the social presence of the institution. In addition to the Met, the Brooklyn Museum, San Francisco Museum of Modern Art, and Indianapolis Museum of Art all have implemented positions committed to online social networking. ${ }^{34}$ Social networking has revolutionized museum management and practice by establishing new positions and whole departments in order to effectively increase their institutions' online presence.

\footnotetext{
32 “@metmuseum," Twitter, accessed June 1, 2011, http://twitter.com/metmuseum.

${ }^{33}$ Kennedy, "The Met's Plans for Virtual Expansion," Section $C_{1}$.

${ }^{34}$ Carol Vogel, "Four To Follow." The New York Times, March 16, 2011, Section F24.
} 
Specifically trained positions centering on technological innovations, such as Twitter, have become necessary. Museum Basics, states, "The success of a museum will be dependent on the interest and enthusiasm of the museum's staff in meetings its objectives." ${ }^{35}$ Now, the goal of a well positioned institution must be to have an informed staff and specialized approach to reaching and sustaining followers effectively through an online presence, and Twitter must be part of that presence. 33 Million People in a Room, by Juliette Powell, states, "Amplifying your ability to connect with people and maintain relationships could create a competitive advantage and higher economic performance for you and your company. ${ }^{36}$ The Met is improving communication by expanding the way they use technology. By adjusting to cultural change through specialized departments and positions, museums better control the information flow on Twitter and effectively inform, respond, and connect with additional followers as a result.

\section{Brooklyn Museum (@brooklynmuseum)}

Shelley Bernstein at the Brooklyn Museum is the Chief of Technology, another specialized position found frequently in larger institutions. Bernstein works exclusively with the museum's Twitter, Facebook, and Flickr accounts and continually monitors their online presence. Having recently reached 270,185 followers on Twitter, Bernstein focuses the Brooklyn Museum's social networking strategies on strengthening its online community through unique and engaging

${ }^{35}$ Ambrose \& Paine, 275.

${ }^{36}$ Powell, 13. 
content. ${ }^{37}$ Bernstein proposes all museums experiment with their content to uncover the most effective forms of connecting with an audience. Having established a significant following, the Brooklyn Museum has learned what content elicits a response from their followers. A recent MuseumNext blog, highlights Bernstein's critical strategies to engaging an audience, stating, "being honest will help your community gain trust in your organization and make for a better and richer exchange." 38

Tweeting etiquette varies between institutions, however, the Brooklyn Museum's tweets aim to deliver content that is reliable and authentic. Bernstein explains Twitter content needs to be multi-directional and able to attract and connect with a variety of audiences in a relaxed setting that welcomes all responses. In doing so, museums must avoid solely broadcasting and advertising their institution on Twitter and instead create authentic content that relates a personal experience to followers. Authenticity conserves an audience's interest and provides for superior connections, appropriate for the informal environment Twitter provides. ${ }^{39}$ Transparency, furthermore, breaks down barriers and allows museums to personalize content and provide a platform for gaining trust with followers. See page 50, Figure Four, for two examples of tweets from the Brooklyn Museum that positively builds trust with their audience. Jenny Kidd's article, Enacting Engagement Online, states transparency in museums can,

${ }^{37}$ Carol Vogel. "The Sprit of Sharing." The New York Times, March 16, 2011, Section F1.

${ }^{38}$ Agenda Assoc., "Shelley Bernstein and Will Cary from the Brooklyn Museum take the floor," (blog), Museum Strategy, July 8, 2009, accessed June 9, 2011, http://www.museumstrategyblog.com/museum_strategies/2009/07/shel.html. ${ }^{39}$ Ibid. 
"more genuinely lend themselves to the inclusion and community, and that can even begin to impact on on-site activity. ${ }^{\not 40}$ Twitter offers the opportunity for museums to exhibit different sides of management by dispensing content that would often be inaccessible otherwise.

Currently, the Brooklyn Museum is experimenting with behind-the-scenes content or insider-looks at the inner workings of museum management and exhibition, including the scheduled 2013 exhibition on mummified animals. ${ }^{41}$ In spring 2011, the museum received thirty-five different mummies, which they snapped pictures of and posted to their Twitter account. Curators tweeted about their thought processes for the future exhibition, Bernstein posted photos of the scanning process and discovery of what animal each mummy encapsulated, and conservators offered their observations of the mummies. Tweets were educational and interesting for followers as the execution and status of the mummified objects were actively updated allowing followers to view the inner workings of the museum. ${ }^{42}$ The Brooklyn Museum's behind-the-scenes tweets provided audiences with authentic, educational, and informative content. The goal of the Brooklyn Museum's behind-the-scenes strategy is to deliver creative content that connects with audiences through online experiences, while influencing individuals to learn more by attending the exhibition in 2013.

\footnotetext{
${ }^{40}$ Jenny Kidd, "Enacting Engagement Online: Framing Social Media Use for the Museum," Information Technology \& People 24, no. 1 (2011): 64-77.

${ }^{41}$ Matt Flegenheimer, "Animals Did The Darndest Things." The New York Times accessed June 17, 2011, http://cityroom.blogs.nytimes.com/2011/06/17/animalsdid-the-darnedest-things/.

42 “@brooklynmuseum," Twitter, accessed June 1, 2011, http://twitter.com/Brooklynmuseum.
} 


\section{Cincinnati Art Museum (@cincyartmuseum)}

The Cincinnati Art Museum has a smaller following in comparison to larger institutions, such as the Brooklyn Museum and the Met. Reaching 14,698 followers, the Cincinnati Art Museum applies an educational approach toward building more interest in their institution by employing links as a principal strategy. Linked information is optional to viewers and most tweets provide the necessary information within the 140 given characters. Links, however, are additional tools to learning and satisfying curiosities. Tweets comprised of links encourage followers to further educate themselves on museum collections, exhibitions, and current endeavors, with the optimism that interested online experiences will foster additional on-site experiences. ${ }^{43}$ See page 51 , Figure Five, for poor linking examples by Art Hotel, an institution in Lancaster, PA, similar to Lousville's 21c Museum Hotel.

Since the Cincinnati Art Museum is free to the public, occasional links to membership pages can increase financial support, however, CAM avoids broadcasting on the subject and therefore links membership pages infrequently. Nonetheless, these rare tweets drive traffic to membership and donation pages, creating possible revenues exclusive of time-consuming funding techniques. In addition, other links include, website information, special events, blogs, printable materials, and articles. ${ }^{44}$ CAM's tweets are created to interest followers on the

\footnotetext{
43 “@ cincyartmuseum," accessed June 1, 2011,
} http://twitter.com/cincyartmuseum.

${ }^{44}$ Amy Mengel, "Social Media Smackdown: Tacome Art Museum vs. Cincinnati 
day-to-day activities and current events of the museum.

Every Wednesday, CAM delivers a "Work of the Week" tweet, which links to a photo on their website of a work of art that is in the museum's collection. See page 52, Figure Six, for an example tweet. The "Work of the Week" is aimed at educating followers on particular works of art that CAM believes needs further explanation and recognition and would hopefully be of interest to audiences. Linking a photo of a work of art in the museum collection additionally induces followers to view the artwork in person, increasing on-site attendance rates. ${ }^{45}$ American Association of Museum published The Digital Museum: A Think Guide, stating, "If greater productivity means more effective education to a larger audience about museum collections, then using the Web should be a priority for every museum. ${ }^{46}$ CAM's goal is to educate, broaden their audience, and increase connections both online and offline. Linking is a straightforward strategy the Cincinnati Art Museum utilizes to reinforce the value of their institution and its mission.

\section{New Museum (@newmuseum)}

The New Museum in New York City has reached 30,863 followers by actively utilizing Twitter in methods larger museums, such as the MOMA, Met, and the Brooklyn Museum are still experimenting with. In spring 2011, the New

Art Museum." Social Media Today. accessed June 10, 2011, http://socialmediatoday.com/index.php?q=SMC/119396.

${ }_{46}^{45}$ Mengel, "Social Media Smackdown."

${ }^{46}$ Thomas \& Hecht, 148. 
Museum held an ad campaign for George Condo's exhibition entitled, "Mental States," via Twitter, concentrating primarily on the interactivity between the museum and its audience. Followers were asked to visit the exhibition and tweet one word that describes their reaction to their experience with the hashtag, \#GeorgeCondo. ${ }^{47}$ Newswire's press release on the exhibition stated, "The campaign will use social media technology to reinvent our fundamental sense of what constitutes art criticism in the 21 st Century...The end result represents a revolutionary new way of thinking about art that is sure to influence other forms of criticism. ${ }^{48}$ The New Museum welcomed all responses and awarded a prize to the weekly response that was retweeted the most frequently, a one-year individual membership to the museum and free admission on their next visit. A creative and valuable incentive fuels interactivity, participation, and reactions. Some of the winning responses included, "sensational," "cheeky", "eyeboggling," "psychohistorical," and "abstranomical." ${ }^{49}$ For an example of a tweet the New Museum awarded a prize, see page 53, Figure Seven. Steven Tepper, Engaging Arts, states, "They (audiences) seek the cognitive satisfaction that comes from the opportunity to formulate and express an opinion in public context. ${ }^{n 50} \mathrm{By}$ utilizing innovative strategies for encouraging interaction, as employed in the

\footnotetext{
47 “@newmuseum," Twitter, accessed June 1, 2011, http://twitter.com/newmuseum.

${ }^{48}$ PRNewsWire, "Innovative New Campaign for George Condo Exhibit at the New Museum Brings Together New York Times and New York Tweets."

PRNewsWire. accessed June 10, 2011, http://www.prnewswire.com/newsreleases/droga5-reinvents-art-criticism-in-the-age-of-social-media118504949.html.

49 "George Condo: Mental States," New Museum, accessed June 22, 2011, http://www.newmuseum.org/quotes/?recent\#reactions.

${ }^{50}$ Tepper \& Ivey, 117.
} 
George Condo campaign, the New Museum is modeling their mission, "New Art - New Ideas. ${ }^{" 51}$

A recent email-interview with New Museum's Marketing Manager and Twitter account supervisor, Annie Wachnicki, explains additional aspects of their social networking approaches. Being a smaller institution, a separate social networking department is often not possible given budget constraints, however, the responsibilities are distributed amongst several existing departments. Wachnicki states, "We try to balance museum news, relevant news, conversations, and listening. I compose and schedule tweets with input from all museum departments, including curatorial, education, press, registrars, visitor's services, and membership departments. Our staff has embraced it and we are thrilled to have a new community online. ${ }^{.52}$ The New Museum's goal to balance and deliver information from multiple sources provides interactivity to a wide range of interested followers and reshapes the meaning of participation within museum environments.

\section{1c Museum Hotels (@21chotels)}

Our local Louisville contemporary art museum, $21 \mathrm{c}$, is currently reaching new heights on Twitter, with 3,485 people following. ${ }^{53}$ The smallest institution of the five examples, $21 \mathrm{c}$ is employing Twitter as a strategy for promoting

\footnotetext{
51 "Mission Statement," New Museum.org, accessed June 22, 2011, http://www.newmuseum.org/about/mission_statement/.

${ }^{52}$ Annie Wachnicki, e-mail message from Marketing Manager, New Museum, March 17, 2011.

53 “@21chotels," Twitter, accessed June 1, 2011, http://twitter.com/21chotels.
} 
constructive feedback. Albert Einstein once said, "We cannot solve our problems with the same thinking we used when we created them.."54 $21 c^{\prime}$ s tweets provide answers by listening to inquiries that are asked of the museum by its community. Open communication establishes both complaints about problems, as well as compliments, allowing improvements, which $21 \mathrm{c}$ works to implement.

In a recent email-interview, Monica Claerbout, the Director of Special Projects and 21c's Twitter Supervisor, explains the protocol 21c uses to interact with followers, stating:

I let our current events, exhibitions, promotions, and press mentions guide about $80 \%$ of our Twitter content. The other $20 \%$ of content is done 'on the fly' - reaching out directly to users that have posted about their visits or answering questions for prospective guests. Twitter is conducive to cultivating new fans, connecting with like-minded groups, and listening in on the general buzz in our community. ${ }^{55}$

21's Twitter account is most responsive of the five museums. Listening and responding to follower's reactions, requests, and emotions are critical to the museum's endeavor to harness feedback, identify problems, and improve as a result. Claerbout also states:

I think my favorite feedback from Twitter actually revolves around what most companies dread - the guest complaint. While I hate to hear when guests experience problems, we've had a few instances where I was able to pick up an issue, relay it to our management team, and correct the issue in real time. I think people are excited to know there's a real person, involved behind the scenes, that cares about their tweets and is sharing relevant content that enriches their experience in the museum. It adds another layer to our commitment to modern Southern Hospitality. ${ }^{56}$

Positive feedback from the museum counteracts the flow of negative feedback

\footnotetext{
${ }^{54}$ Thomas \& Hecht, 153.

${ }^{55}$ Monica Claerbout, e-mail message from Director of Special Projects, 21c, March 21, 2011.

${ }^{56}$ Claerbout, email-interview, March 21, 2011.
} 
from the community. Allowing responses from individual experiences to improve a museum's quality generates coauthorship between the institution and its audiences. Steven Tepper, Engaging Art, states coauthorship is, "experiences that converge in and around an arts event to provide useful information, opportunities to process that information, and finally, a follow-through experience that allows for synthesis, debate, and consensus on the meaning of the arts event. ${ }^{~}{ }^{57} 21 \mathrm{c}$ embraces the subjectivity in which they can learn and build from. The advancement of museum social networks is building expectations of a social responsibility to communicate audience focused, community based, and visitor oriented objectives. Stephen Weil states, "Museums must fulfill all their functions and not subordinate those related to communication and the public to those of collecting and preserving. ${ }^{\text {"58 }}$ Museums are recognizing the capacity of social networking in improving goals such as, education, participation, audience outreach, and online and offline attendance. Whether through feedback or behind-the-scenes content, Twitter's social networking approach provides the five museums with communication that is both responsive and interactive. Refer to page 54 , Table One, for a comprehensive table on statistics, including number of followers, total tweets, average tweets per day, date established, and average new followers per day on all museums evaluated throughout this thesis.

\footnotetext{
57 Tepper \& Ivey, 119.

${ }^{58}$ Weil, "Rethinking the Museum," 74.
} 


\section{CHAPTER FIVE}

\section{AMERICAN MUSEUM OF NATURAL HISTORY: DOING IT RIGHT}

Each museum's approach to building an audience, seeking appropriate exposure, educating, and engaging vary. The same is true for how museums pursue social networking strategies using Twitter. The American Museum of Natural History's (AMNH) approaches, however, are most innovative among those I have surveyed in harnessing Twitter's advantages and as a result provides benefits to the institution that the others have not gained. AMNH is superior to other museum Twitter accounts because it embodies a creativity most museums have not discovered. In chapter five AMNH's approaches to ease of use, education, engagement, and exposure are revealed. With examples that demonstrate the institution's uniqueness and success using Twitter, it becomes apparent that their integrated and innovative strategies provide the best opportunity to fully exploit the new opportunities that social media such as Twitter now make available to museums.

The American Museum of Natural History in New York City is a recent convert to use of Twitter. At the start of my research, in March 2011, the museum had 8,192 followers, presently, 31,431 followers have been drawn in within the past four months. In November 2010, the AMNH began building audiences through an online presence. Since then, it has developed new methods of 
engagement superior to many other museums. Much like other museums on Twitter, AMNH employs a variety of similar techniques, such as linking to webpages, related blogs, articles, and membership pages. AMNH also uses methods competing museums utilize, such as, asking questions, replying to their followers, building from feedback, sharing behind-the-scenes photos, and updating consistently. What makes AMNH distinct from other museums, however, is their ability to harness these same approaches other museums use, while creating additional new methods and doing-so with originality. ${ }^{59}$

AMNH's most groundbreaking endeavor is called a "tweet-up." A tweet-up is an event held to bring individuals on Twitter together. Users are asked to sign up for a tweet-up via AMNH's Twitter account and typically between fifty and one hundred individuals are chosen to attend. A tweet-up, however, requires those in attendance to tweet at the event about their experience. AMNH's goal for tweetups is to reach as many people as possible by asking each attendee to tweet to their individual followers about the museum. See page 55, Figure Eight, for an example of AMNH's tweet to inform followers of the most recent tweet-up.

On January 12, 2011, tickets to AMNH's tweet up, which included a curator's lecture and private showing of the newest exhibition, Brain: The Inside Story, were distributed for free to first seventy-five individuals who signed up. Once chosen, the seventy-five people in attendance were asked to tweet a personal review, comment, or photo of their experience while visiting Brain: The Inside Story exhibition, which was not open to the public yet. Tweets were

${ }^{59}$ Twitter, "@AMNH.” Accessed June 22, 2011. http://twitter.com/AMNH 
identified with the hash tag, \#AMNHtweetup, making the trend simpler to identify online. ${ }^{60}$ The New York Times, Speaking Digitally About Exhibits, stated 318 total tweets came from the event, reaching a potential 200,000 individuals on Twitter. AMNH also conducted a survey with tweet-up participants and with its successful results a second tweet-up in March 2011 was held, hosting 100 participants. ${ }^{61}$ Elizabeth Merritt, director of American Association of Museums Center for the Future of Museums, states of Twitter, "It has revolutionized the way museums are communicating with their audiences," and tweet-ups are a clear example of such transformations. ${ }^{62}$ The American Museum of Natural History has taken the time to learn what causes their audience to participate with Twitter and has increased its museum attendance by developing and utilizing a unique approach.

In addition to the museum's tweet-ups, additional different measures of engaging and educating audiences are employed by $\mathrm{AMNH}$. Currently, the museum has created an additional twitter account, @ giantdino, for information related directly to the newest exhibition, The World's Largest Dinosaurs. The centerpiece for the exhibition is the Mamenchisaurus Hochuanensis, a 60-foot dinosaur, in which AMNH has humorously brought to life as the Twitter account's narrator. AMNH asks Twitter followers to help nickname the newest addition to the museum and are rewarding three finalists and a winner, chosen for the most

60 "Brain: Inside Story Tweet-Up," AMNH, accessed June 22, 2011, http://www.amnh.org/museum/brain.php.

${ }_{61}$ Jennifer Preston, "Speaking Digitally About Exhibits." The New York Times, March 16, 2011, Section F26.

62 Ibid. 
creative name, with an ipod touch and free admission. ${ }^{63} \mathrm{AMNH}$ is additionally offering a special event for Twitter followers to see The World's Largest

Dinosaurs before its debut by asking its followers to apply via Twitter to attend and those selected are invited to a breakfast and discussion on the exhibit at the museum. ${ }^{64}$

The American Museum of Natural History initiated a "Museum Memory Day" on May $17^{\text {th }}, 2011$. Followers were asked to tweet their favorite memories of the museum with the hashtag, \#musmem. ${ }^{65}$ In doing so, AMNH allowed users to speak openly about their experiences visiting the museum, bringing to a public forum all kinds of feedback. Visitors to the museum can download $A M N H$ Explorer, which is an iPhone app that is accessible anywhere throughout the museum. It serves as a human GPS system, making visitor experiences more seamless so they can avoid getting lost in the 46 halls of the museum. Users search $A M N H$ Explorer by floor and hall. The app includes detailed descriptions of objects and exhibitions, which visitors utilize as a learning tool. AMNH also added an additional feature to the app, which gives visitors the option to tweet their favorite locations and objects within the museum. ${ }^{66}$

The American Association of Museums published book, The Digital Museum: A Think Guide, states, "Museums must broaden their institutional focus

63 "Name the Mamenchisarus Contest," AMNH, accessed June 22, 2011, http://www.amnh.org/news/tag/twitter/.

64 "Museum Hosts Social Media Breakfast For Families," AMNH, accessed June 22, 2011, http://www.amnh.org/news/tag/social-media/.

65 Twitter, "@AMNH.” Accessed June 22, 2011. http://twitter.com/AMNH

${ }^{66}$ Sam Grobart, "Multimedia Tour Guides on your Smartphone." The New York Times, March 16, 2011, Museums Specials Section. 
beyond an organization rooted in an exclusive place in real time to a ubiquitous source of around-the-clock educational experiences." ${ }^{67}$ The American Museum of Natural History's Twitter account delivers continuous educational resources and ease of museum navigation designed to increase enjoyment of the visitor's inhouse experience through $A M N H$ Explorer, allows direct audience participation through Museum Memory Day, tweet-ups, and provides incentives for continued and deeper engagement through special events directed especially to Twitter users. All these expanded uses of Twitter, in addition to the other strategies that competing museums employ, makes their Twitter program unique and successful in accomplishing the goal of "real-time" usefulness for the user. These strategies all increase museum exposure, education, and engagement. Followers are provided a variety of methods of connecting with the museum and developing dialogue on museum subjects.

It is apparent that education is central to $\mathrm{AMNH}$, as its mission statement, "To discover, interpret, and disseminate-through scientific research and education-knowledge about human cultures, the natural world, and the universe," points out. Twitter serves as a new and alternative avenue for educating followers by providing opportunities that enhance experiences both online and offline. ${ }^{68}$ These alternative and additional methods $\mathrm{AMNH}$ is using helps create influence, which is important aspect of a prosperous Twitter site. The American Museum of Natural History is breaking new ground in the way

\footnotetext{
67 Thomas \& Hecht, 77.

68 "Mission Statement," AMNH, accessed June 22, 2011, http://www.amnh.org/about/mission.php.
} 
museums use social media, particularly Twitter, to enhance interactions with visitors. These Twitter uses build audiences, educate users and make the institution a more vital part of the daily life of its followers/members. 


\section{CHAPTER SIX \\ MEASURING SUCCESS}

The advancement and growing sophistication of social networking also provides museums new ways for measuring their success. As museums build their online influence with social networking platforms, several methods of evaluating their effectiveness have become available. Twitter's simplicity of use continues with it offering additional features that allow measuring how often individual accounts are used. Chapter six highlights several valuable ways of measuring success on Twitter.

The number of followers an account attains or the number of retweets received in a day, month, year, are amongst dozens of easily accessible paths for acquiring data on the health and success of an institution's online presence. More detailed statistics, however, are available to institutional users on their Twitter account, for example, tweets per hour, number of replies per minute, and what tweets caused the most discussion and exchange between users. See page 56, Figure Nine, for an example of the statistics Twitter shares on its website. Museums are able to graph the statistics of their social network as a reference on what methods are most used by individuals and which methods are 
least utilized. This information, which Twitter provides, serves as a powerful tool for preserving and improving museums' online identities. ${ }^{69}$

Twitter also offers third party applications for measuring success. These third party applications available at alternative, (non-Twitter) websites, however are still affiliated with Twitter and remain free to institutions that want to evaluate the effectiveness of their Twitter programs. The following are four influential websites for measuring success on Twitter:

\section{Tweet Grader}

Tweet Grader is a simple tool to help answer the question, "How influential are you on Twitter?" This application evaluates account activity, amount of followers, retweets, and trends and compares it to the millions of other accounts existing to develop a grade that best describes the influence of a users account. When typing in @ AMNH, the grade was 100\% and @21chotels was $98.2 \%$. Tweet Grader also provides tips for improving each grade. This does not require any additional accounts to be registered to receive a grade and remains free to all Twitter users. ${ }^{70}$

Tweet Deck

Tweet Deck allows users to keep a more organized account and improve the quality of communication. This feature permits users to break down followers

69 "Twitter Business: Advertiser Analytics," Twitter, accessed July 5, 2011, http://business.twitter.com/advertise/analytics.

70 "About Tweet Grader," Tweet Grader, accessed July 5, 2011, http://tweet.grader.com/. 
and discussions into separate pages online, creating a space focused on generating responses to specific entities. Users customize their followers list into different divisions to effortlessly inform and engage with specific groups of users. This application creates added visibility by breaking down followers into sets and allowing the account holder to witness what other Twitter users are in dialogue about, which in turn can be utilized to measure the effectiveness of the account. ${ }^{71}$

\section{Tweet Beep}

Tweet Beep measures responses to an individual account by providing an alert system. A user registers for free for a tool that tracks all conversations on the entire Twitter network that mentions their account and in return receives a notice on any positive and negative discussions circulating. Users choose to receive hourly, daily, or monthly updates through email or text to track discussions online. Tweet Beep manages online reputations, keeps account holders informed, and gives users the opportunity to counteract any negative discussions and build success as a result. ${ }^{72}$

\section{Twitter Counter}

Twitter Counter is geared toward users that are actively searching for ways to build their following. The statistics Twitter Counter provides are detailed and specific. Graphs, excel spread sheets, and timelines are available to users,

\footnotetext{
71 "About Tweet Deck," Tweet Deck, accessed July 5, 2011, http://www.tweetdeck.com/about/.

72 "About Tweet Beep," Tweet Beep, accessed July 5, 2011, http://tweetbeep.com/about.html.
} 
as well as quick comparisons to competing accounts. This feature allows users to track their account activity daily, monthly, and yearly. Additionally, Twitter Counter is informing users with feedback on the number of people that choose to un-follow an account, allowing that user to correct any negative habits. ${ }^{73}$

Third party applications are simple, free, and accessible avenues for measuring the success of efforts to develop, build and employ Twitter as strategy to engage audiences. Museums online identities benefit from using these evaluation tools to improve their methods of using Twitter. Refer to page 57, Figure Ten, for an example of the statistics Twitter Counter provides.

In addition to third party electronic applications, museums can also measure their Twitter success offline. The American Museum of Natural History's survey of the seventy-five people in attendance at their first tweet-up demonstrates use of more traditional evaluation methods adapted for current programs. Museums can also offer discounts for admission by asking visitors to mention a particular tweet at the ticket counter and as a result measure the ratio of on-site museum visitors to those museum visitors informed by Twitter. These applications tailor a museum's Twitter account, improving the quality of each tweet, and build from its feedback. The American Association of Museums, The Digital Museum: $A$ Think Guide, states, "A range of new possibilities exists for using technology for evaluation, and, in turn, for evaluating museum technology experiences to inform professional practices and improve user experiences."174

\footnotetext{
73 "About Twitter Counter," Twitter Counter, accessed July 5, 2011, http://twittercounter.com/pages/about?ref=footer.

74 Thomas \& Hecht, 186.
} 
Twitter's "real-time" feedback is in its purest and simplest form, a form of instant critique. 


\section{CHAPTER SEVEN CHALLENGES OF SOCIAL NETWORKS}

Museums are met with both small and substantial challenges in constructing a social network if they hope to prosper from such efforts. The challenges to successfully build audiences, create influence, and promote connectivity confront museums continuously. Chapter seven highlights the challenges museums face as they transition away from traditional museum methods of communication and strive to keep pace in an era of rapid technological change.

The first challenge is for museums to make the decision to build a more socially responsive, community-based institution, particularly one that empowers its audience. Some museums will try to avoid giving up any institutional authority to the informal social networking environment. However, it puts itself at considerable risk if it doesn't fully engage with a generation that has grown up with technology and is fully fluent in its uses. It seems increasingly apparent museums must consider alternative electronic and technology-based avenues for communicating and educating. The American Association of Museums article, $A$ Clear View: The Case for Museum Transparency, states, "The ultimate goal is to raise the standards of the profession as we step into unchartered territory. The unexpected, rewarding result is a more honest organizational culture in which 
constructive dissent and failed experimentation are not punished, professionwide innovation is favored over score-keeping about our successes and going to work in the morning is a continuous adventure..75 Museums are met with an additional challenge of forming new departments and structures to stay up to date and current, on the part of museum staff, with both the content, the response to users and the technology.

As this thesis demonstrates, it is apparent that museums are moving past traditional methods of communication and building social networks that promote creative thinking and collaboration with the community. Duncan Cameron's article, The Museum, a Temple or the Forum?, in Gail Anderson's Reinventing the Museum: Historical and Contemporary Perspectives on the Paradigm Shift, claims museums are modernizing themselves away from sacred settings and transitioning into a common-ground for communication. Cameron states, "Museums cannot only be places of worship and cult, but also places where people meet in order to discuss current issues, places of experimentation and innovation, places that welcome controversy." ${ }^{\prime 76}$ Twitter presents museums with opportunities to connect with individuals for personally directed discussion. Twitter can allow the institution to learn from experimentation, and quickly get feedback that fosters creativity when it offers innovative programs. Finally, Twitter permits feedback, possibly courting controversy, but also diffusing it by

\footnotetext{
${ }^{75}$ Maxwell Anderson, "A Clear View: The Case for Museum Transparency,"AAM: Museum Magazine, March 2010, 48-53.

${ }^{76}$ Duncan Cameron, "A Museum, the Temple or the Forum?," In Reinventing the Museum: Historical and Contemporary Perspectives on the Paradigm Shift, ed. Gail Anderson, (Oxford: AltaMira Press, 2004), 24.
} 
empowering its audiences. Twitter as method that allows expression of an institution's community members, makes the decision for museums to become a "common ground" a much conceivable and possible emerging trend.

Social networking challenges, however, do not subside with the decision to implement a social networking program. Museums are confronted with the challenge of remaining relevant to its audiences without sacrificing the integrity of the museum's mission. Gail Anderson, Reinventing the Museum, exclaims, "In today's museum community, some museums elect to remain unchanged, and run the risk of becoming anachronistic. Others continue to question assumptions and motives in an effort to remain fresh in a dynamic world. There are lessons to be learned from both. The challenge is for museum leaders to be alert, questioning, and committed to the ongoing challenge of making museums a relevant and integral part of civic life. ${ }^{\prime 77}$ Museums joining social networks, such as Twitter, are challenged to balance their focuses on scholarship, preservation, and collections with the constant demands of social media and popular culture. Without sacrificing the mission, museums are also challenged to deliver credible content that influences and interests followers. The American Association of Museums, The Digital Museum: A Think Guide, states, "The use and repurposing of content across various media-platforms, not only maximizes its potential value but also ensures that visitors' preferred channels of communication carry the information deemed important to their issues." ${ }^{, 78}$ A museum must recognize the role of the public in determining relevancy and calibrate how much influence the

\footnotetext{
${ }_{78}^{77}$ Anderson, 7.

${ }^{78}$ Thomas \& Hecht, 44
} 
public has on its functions, when utilizing a social networking system.

As challenges are met, however, opportunities to influence a new generation of museum goers form. Twitter is expanding museums' traditional methods of communication and providing them with innovative paths for fostering relevancy and appreciation for the next generation of visitors. The challenges museums face are continual as technological trends emerge and fade. All museums are not on board with social networking, however, those deciding to work through the challenges are given further possibilities toward becoming a more active, established, and dynamic institution. 


\section{CONCLUSION}

Integrating Twitter into museum management can be an effective way to build audiences, promote engagement, and continue education. Lynda Kelly and Angelina Russo, From Ladders of Participation to Networks of Participation: Social Media and Museum Audiences, states "As museums attempt to make their collections and expertise more accessible on audience terms, certain concessions to experimentation will need to be made, allowing audiences to express what it is that they value as opposed to being offered a learning environment focused exclusively on institutional views. ${ }^{.79}$ Twitter is precisely a platform for welcomed opinions, educational growth and cultural debate within the entire museum community from experts like curators, to engaged members through first-time visitors. Acting as a gateway for maximizing connections and discovering opportunities, Twitter has developed into a professional responsibility of the modern museum. As established through examination of the six museums identified throughout this study, the new resources Twitter makes available changes the standards of museums and their operations, providing new and distinctive opportunities for individual growth, community engagement and ultimately institutional success.

${ }^{79}$ Kelly \& Russo, 10. 


\section{FIGURE ONE}

\begin{tabular}{|c|c|c|}
\hline II AT\&7 & 11:50 PM & $9 \%$ 粡 \\
\hline MNH & ANINH & \\
\hline$v$ & \multicolumn{2}{|l|}{$\begin{array}{l}\text { A big thanks to everyone who came } \\
\text { out for the \#picturingscience } \\
\text { tweetup tonight! We had a great } \\
\text { time! }\end{array}$} \\
\hline & $\begin{array}{l}\text { AMNH } \\
\text { RT @RamonaRightNow: } \\
\text { \#PicturingScience From a picnic } \\
\text { million years ago. } \\
\text { http://t.co/8TpxJQ3 }\end{array}$ & 100 \\
\hline 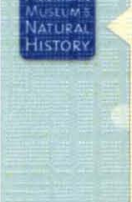 & $\begin{array}{l}\text { AMNH } \\
\text { Learning how CT scanners help } \\
\text { scientists study girdled lizards } \\
\text { \#picturingscience } \\
\text { http://t.co/FgwsKmW }\end{array}$ & $4 d$ \\
\hline & & \\
\hline
\end{tabular}

Figure 1: An image of the American Museum of Natural History's Twitter feed from a mobile device. The use of trends (\#), retweets (RT), replies (@), and links are all visible in this example. ${ }^{80}$ (Refer back to page 5 )

80 “@amnh," accessed June 1, 2011, http://twitter.com/amnh. 


\section{FIGURE TWO}

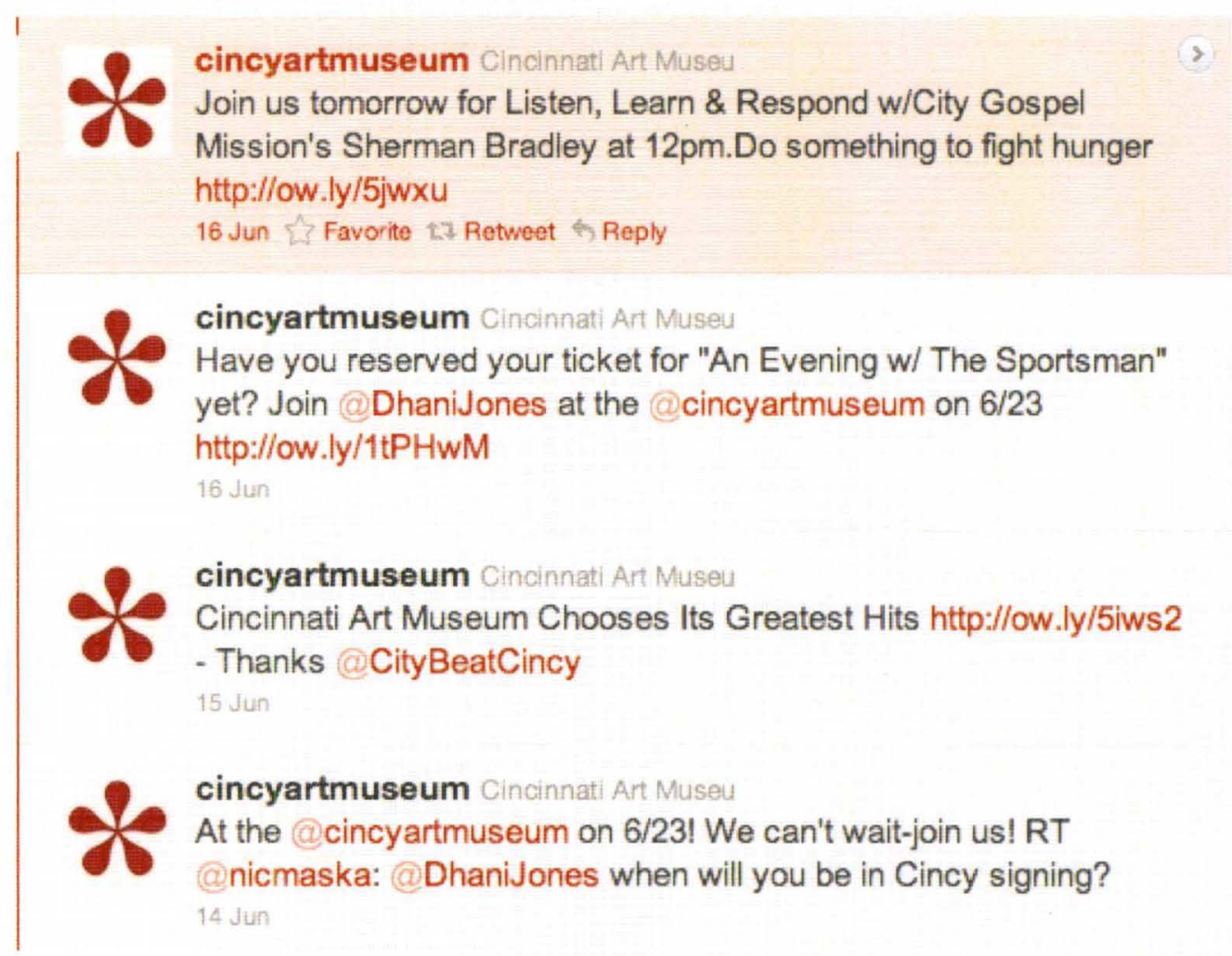

Figure Two: An image of the Cincinnati Art Museum's Twitter feed. The use of linking, replies, and educational outreach are visible as tweets are informing audiences on events. ${ }^{81}$ (Refer back to page 16)

81 “@ cincyartmuseum," accessed June 1, 2011, http://twitter.com/cincyartmuseum. 


\section{FIGURE THREE}

\section{metmuseum metmuseum}

JaJahannes Yes! Here's a link to Parks's Red Jackson:

met.org/nZchyz Nice description but there's no image up yet, unfortunately.

14 Jul

metmuseum metmuseum

CoreyLGarcia Feel free to share works of art from other museums, galleries, collections. I just want to hear from you.

$14 \mathrm{Jul}$

metmuseum metmuseum

Art is integral to a nation's identity. Which works do you associate with your homeland? Browse works: hitp://met.org/f42Puz

\# Connections $14 \mathrm{Ju}$

Figure Three: An image of the Metropolitan Museum of Art's Twitter feed. This example shows the museum replying to individual inquiries (example:

@ JaJahannes), requesting to hear further from followers, and asking questions as forms of engagement. ${ }^{82}$ (Refer back to page 18)

82 “@ metmuseum,” accessed June 1, 2011, http://twitter.com/metmuseum. 


\section{FIGURE FOUR}

\section{brooklynmuseum brooklynmuseum}

Here we go with more \#mapBK - see if you can map these next 50 images... http://bit.ly/p6cDMJ via@shell7

7 Jul Favorite 27 Retweet th Reply

\section{brooklynmuseum brooklynmuseum}

@IAMRCM We wish for better news. Many cuts; this was not the only thing - no more late hrs Fri nights. Not good overall via@shell7 21 Jun Favorite 27 Retweot th Reply

Figure Four: An image of two tweets from the Brooklyn Museum's Twitter feed. Each exemplify the museum's effort to provide authentic information that builds the trust of an audience. For example, each tweet concludes with "via @ shell7," indicating Shelley Berstein personally composed the tweet. Also, Twitter's allows museums to explain current news informally to an audience interested in receiving consistent updates, as seen in the second tweet. These examples provided followers with reliable information directly from the institution they can trust. $^{83}$ (Refer back to page 23)

83 “@brooklynmuseum," accessed June 1, 2011, http://twitter.com/Brooklynmuseum. 
FIGURE FIVE

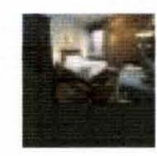

\section{ARTSHOTEL Lancaster ARTS HOTEL}

Viva la VOICE! http://fb.me/zgqcaNeE

3 Jun

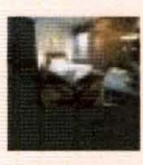

ARTSHOTEL Lancaster ARTS HOTEL

http://login.blastwithbrio.com/t/r-F8EC264AF09EC5D0

http://fb.me/YnDKLWxb

3 Jun fl? Favorite tz Retweet to Reply

Figure Five: An image of Lancaster Arts Hotel's Twitter feed. The links provided are inconsistent and confusing. "Viva la Voice" tells the follower nothing about the link and the second tweet does not provide any clarification to what the follower could be visiting, if they so choose to click on the link. ${ }^{84}$ (Refer back to page 25)

84 “@ARTSHOTEL," accessed June 1, 2011, http://twitter.com/artshotel. 


\section{FIGURE SIX}

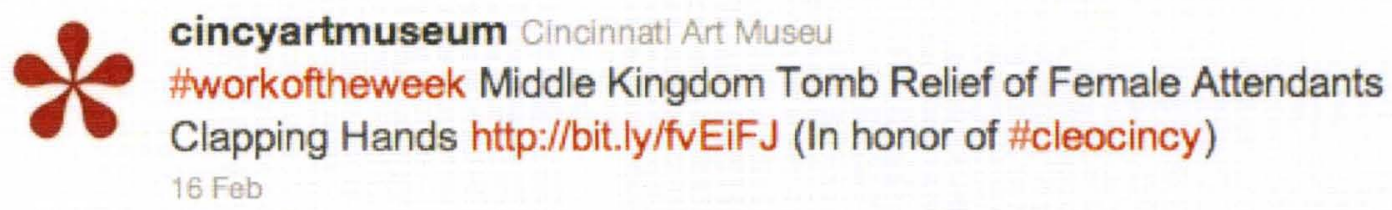

Figure Six: An image of Cincinnati Art Museum's "Work of the Week" tweet. This particular tweet is referencing the Cleopatra exhibition with the hash tag \#cleocincy and every Wednesday's image with the hashtag, \#workoftheweek. ${ }^{85}$ (Refer back to page 26)

85 "@ cincyartmuseum," accessed June 1, 2011, http://twitter.com/cincyartmuseum. 


\section{FIGURE SEVEN}

newmuseum New Museum

Congrats to GeorgeCondo week 6 winners! @karinsatrom won a Membership (freaktabulous), RT'er@Nimadera won free tix! http://bit.ly/gM3161

26 Apr 3 Favorite 23 Retweet th Feply

Figure Seven: An image of the New Museum's tweet to award a winner on the George Condo contest. The hashtag, \#GeorgeCondo references the exhibition.

The winning word was "freaktabulous." ${ }^{\text {"6 }}$ (Refer back to page 27)

86 “@ newmuseum,” accessed June 1, 2011, http://twitter.com/newmuseum. 


\section{TABLE ONE}

\begin{tabular}{|l|c|c|c|c|c|}
\hline Museum & $\begin{array}{c}\text { Total \# } \\
\text { Followers } \\
\text { on 7/20/11 }\end{array}$ & $\begin{array}{c}\text { Average \# } \\
\text { New } \\
\text { Followers } \\
\text { Per Day }\end{array}$ & $\begin{array}{c}\text { Total } \\
\text { Tweets } \\
\text { on } \\
7 / 20 / 11\end{array}$ & $\begin{array}{c}\text { Average \# } \\
\text { Tweets } \\
\text { Per Day } \\
\text { By The } \\
\text { Museum }\end{array}$ & $\begin{array}{c}\text { Date } \\
\text { Established }\end{array}$ \\
\hline @metmuseum & 317,499 & 826 & 3,185 & 6 & $\begin{array}{c}\text { December } \\
19,2008\end{array}$ \\
\hline @ brooklynmuseum & 270,185 & 643 & 3,969 & 3 & $\begin{array}{c}\text { December } \\
4,2008\end{array}$ \\
\hline @ cincyartmuseum & 14,698 & 23 & 1,237 & 2 & $\begin{array}{c}\text { December } \\
4,2008\end{array}$ \\
\hline @ newmuseum & 30,863 & 51 & 2,097 & 2 & $\begin{array}{c}\text { July 14, } \\
2009\end{array}$ \\
\hline @21chotels & 3,485 & 5 & 2,414 & 2 & $\begin{array}{c}\text { December } \\
16,2009\end{array}$ \\
\hline @ AMNH & 31,431 & 548 & 1,455 & 4 & $\begin{array}{c}\text { November } \\
4,2008\end{array}$ \\
\hline
\end{tabular}

Table One: This is a chart of all six museums identified throughout this research in order to help compare and contrast each. Twitter Counter provided these statistics. ${ }^{87}$ (Refer back to page 30 )

87 "About Twitter Counter," accessed July 20, 2011, http://twittercounter.com/pages/about?ref=footer. 


\section{FIGURE EIGHT}

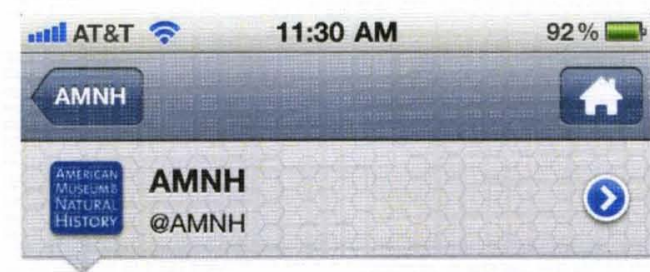

Get a special after-hours look at \#PicturingScience + meet scientists at our next tweetup on $7 / 7$ ! Sign up here http://bit.ly/mrUnbO

June 20, 2011 12:11:11 PM from HootSuite

(A) ॠ

Figure Eight: An image of AMNH's most recent tweet for their third tweet-up on newest exhibition, Picturing Science on July $7^{\text {th }}$. Also providing an easily accessible sign up link. ${ }^{88}$ (Refer back to page 32)

88 “@amnh.” accessed June 1, 2011, http://twitter.com/amnh. 


\section{FIGURE NINE}

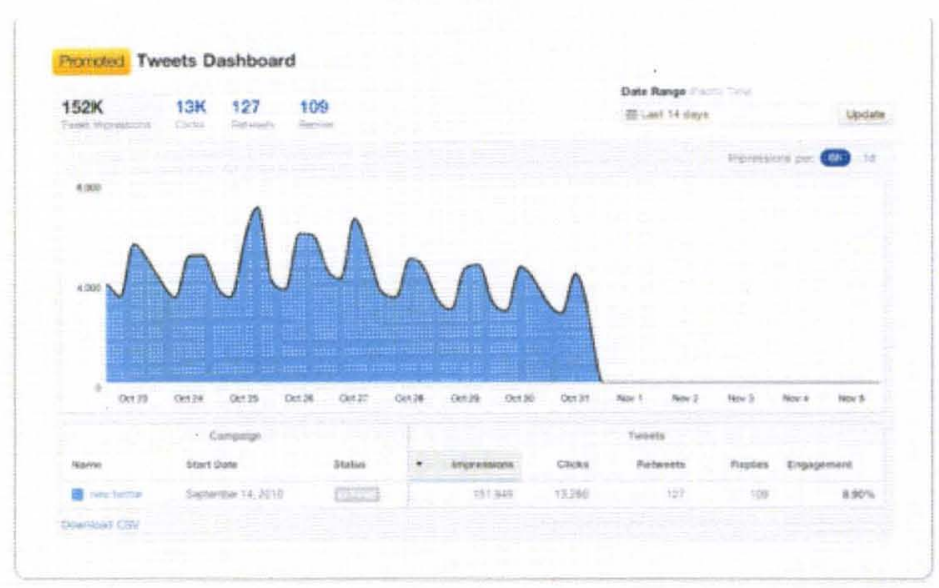

\section{Timeline Activity}

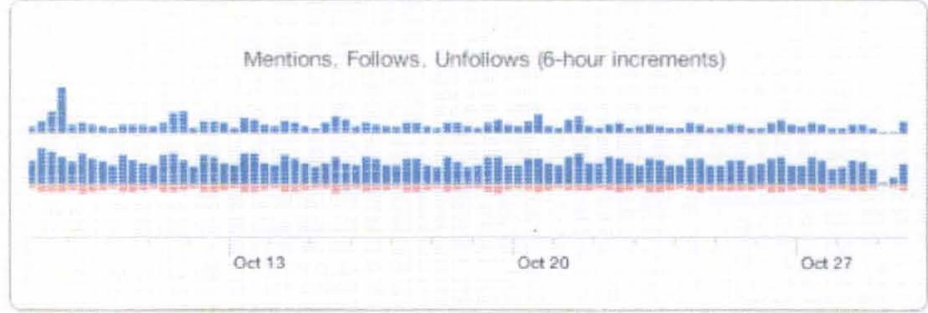

FIGURE NINE: This is an image of a sample of the statistics Twitter provides institutions. ${ }^{89}$ (Refer back to page 37 )

89 "Twitter Business: Advertiser Analytics," accessed July 5, 2011, http://business.twitter.com/advertise/analytics. 


\section{FIGURE TEN}

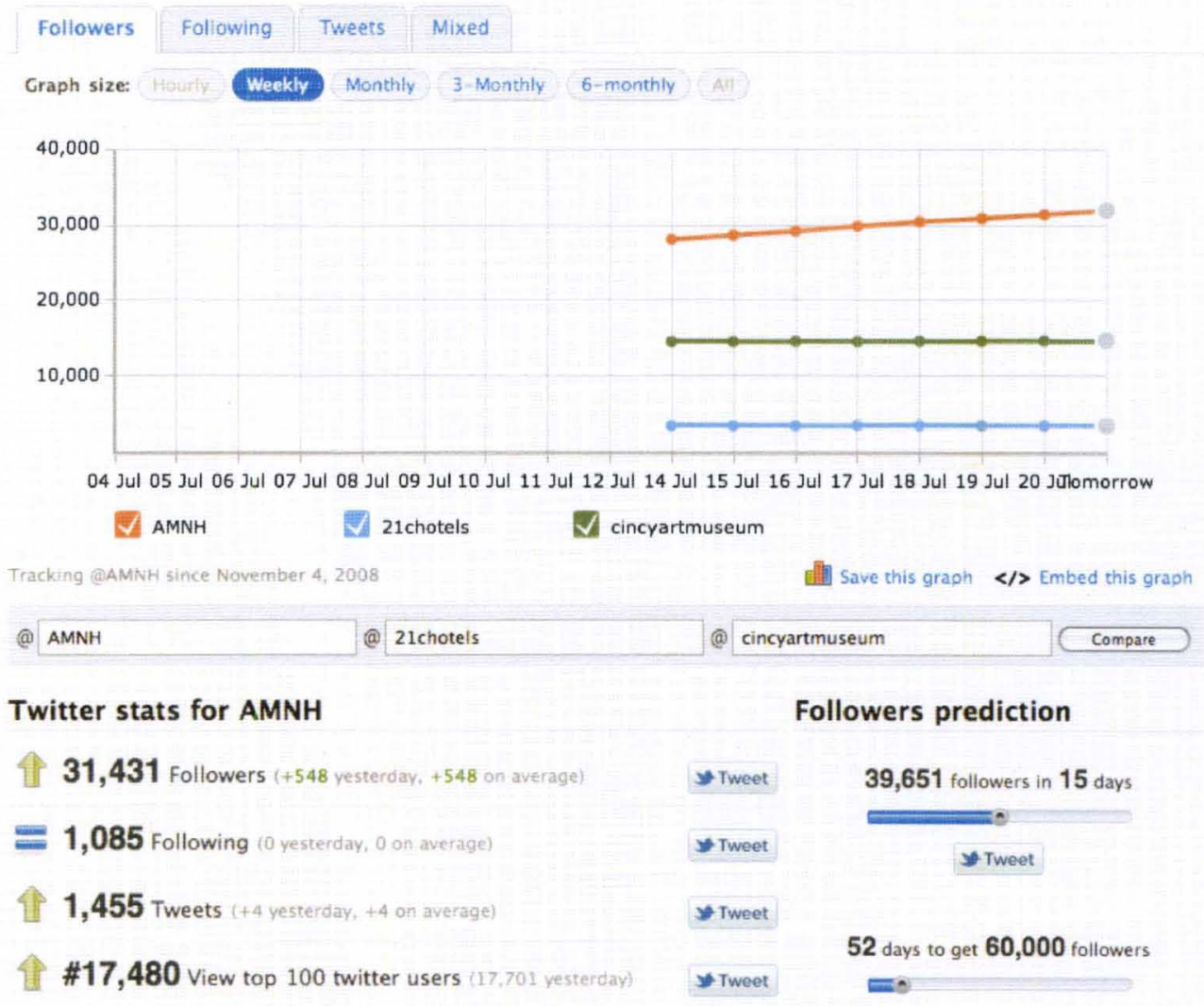

FIGURE TEN: This is an image of Twitter Counter's statistics, comparing

@AMNH to @ 21chotels and @ cincyartmuseum. ${ }^{90}$ (Refer back to page 40)

90 "About Twitter Counter," accessed July 5, 2011, http://twittercounter.com/pages/about?ref=footer. 


\section{REFERENCES}

@ AskACurator. (2011, April 18). 1500+ museums on Twitter, who have I missed out? http://bit.ly/museumtweets2011[Twitter post]. Retrieved from http://twitter.com/\#!/AskACurator.

Agenda Association. "Shelley Bernstein and Will Cary from the Brooklyn Museum take the floor." Museum Strategy (blog). July 8, 2009.

http://www.museumstrategyblog.com/museum_strategies/2009/07/shel.html.

Alexander, Edward \& Mary. Museums In Motion: An Introduction Introduction to the History and Function of Museums. Second ed. Oxford: AltaMira Press, 2008.

Ambrose, Timothy and Crispin Paine. Museum Basics. 2 ed. New York: Routledge, 2006.

Anderson, Gail. Reinventing the Museum: Historical and Contemporary Perspectives on the Paradigm Shift. Oxford: AltaMira Press, 2004.

Anderson, Maxwell. "A Clear View: The Case for Museum Transparency." AAM: Museum Magazine, March 2010, 48-53.

Anderson, Terry. "Self-paced Learners Meet Social Software: An Exploration of Learners' Attitudes, Expectations, and Experiences." Online Journal of Distance Learning Administration, vol. 8, no. 1, 2010. http://www.westga.edu/ distance/ojdla/Fall133/anderson_poellhuber_mcKe rlich133.html.

AMNH. "Brain: Inside Story Tweet-Up." Accessed June 22, 2011. http://www.amnh.org/museum/brain.php.

AMNH. "Name the Mamenchisarus Contest." Accessed June 22, 2011. http://www.amnh.org/news/tag/twitter/.

AMNH. "Mission Statement." Accessed June 22, 2011. http://www.amnh.org/about/mission.php. 
AMNH. "Museum Hosts Social Media Breakfast For Families." Accessed June 22, 2011. http://www.amnh.org/news/tag/social-media/.

Arum, Richard and Josipa Roksa. Academically Adrift: Limited Learning on College Campuses. Chicago: University of Chicago Press, 2011.

Begley, John \& Morrin, Peter. Lecture on museum history, Curatorial Studies, University of Louisville, Kentucky, Fall Semester, 2010.

Bernstein, Shelley. "Where Do We Go From Here? Continuing with Web 2.0 at the Brooklyn Museum." Museums and the Web 2008: Proceedings, Toronto: Archives \& Museum Informatics. March 31, 2008. http://www.archimuse.com/mw2008/papers/bernstein/Bernstein.html.

Cameron, Duncan. "A Museum, the Temple or the Forum?" In Reinventing the Museum: Historical and Contemporary Perspectives on the Paradigm Shift, ed. Gail Anderson, (Oxford: AltaMira Press, 2004), 24.

Claebout, Monica. e-mail message to Director of Special Projects, 21c, March 21, 2011.

Comm, Joel. Twitter Power: How to Dominate Your Market One Tweet at a Time. Hoboken: Wiley \& Sons, Inc., 2009.

Dunlap, Joanna C. \& Patrick R. Lowenthal. "Tweeting the Night Away: Using Twitter to Enhance Social Presence." Journal of Information Systems Education 20, no. 2 (2009): 129-135.

Ferey, Marie-Pierre. "Internet Museums Net New Art Lovers." The Manila Times.net (February 5, 2011), http://www.manilatimes.net/techtimes/internet-helps-museums-net-new-art-lovers.

Flegenheimer, Matt. "Animals Did The Darndest Things." The New York Times (June 17, 2011), Section F24.

http://cityroom.blogs.nytimes.com/2011/06/17/animals-did-the-darnedestthings/.

Gillin, Paul. Secrets of Social Media Marketing: How to Use Online Conversations and Customer Communities to Turbo-Charge Your Business. Fresno: Quill Driver Books, 2009.

Grobart, Sam. "Multimedia Tour Guides on your Smartphone." The New York Times (March 16, 2011), Museums Specials Section, http://www.nytimes.com/2011/03/17/arts/design/apps-give-museumvisitors-multimedia-access.html. 
Grosseck, Gabriela \& Holotescu, Carmen. "Can We Use Twitter For Educational Activities?." Paper presented at the $4^{\text {th }}$ International Scientific Conference eLSE, Bucharest, April 17-18, 2008.

Halter, Heather. 'Moving From a Textbook to Facebook: College Studients' Motivations For Using Social Networking Sites In Education." Masters thesis, The University of Central Florida, Orlando, Florida, 2010.

Kelley, Lynda \& Russo, Angelina. "From Ladders of Participation to Networks of Participation: Social Media and Museum Audiences." Paper presented at the international conference for culture and heritage on-line, Montreal, Quebec, Canada, September 12, 2008.

Kennedy, Randy. "The Met's Plans for Virtual Expansion." The New York Times (February 11, 2011), Section C1, http://www.nytimes.com/2011/02/12/arts/ design/12campbell.html.

Kidd, Jenny. "Enacting Engagement Online: Framing Social Media Use for the Museum." Information Technology \& People 24, no. 1 (2011): 64-77.

Lester, Aaron. "A New Kind of Transparency: Damage Control in the Age of Facebook." The Non-Profit Quarterly (April 12, 2011), http://www.nonprofitquarterly.org/index.php?option=com_content\&view=arti cle\&id=11251:a-new-kind-of-transparency-damage-control-in-the-age-offacebook\&catid $=153:$ features\&ltemid $=336$

Lowery, Courtney. "An Explosion Prompts Rethinking of Twitter and Facebook." Nieman Reports (September 16, 2009), http://www.nieman.harvard.edu/ reports/article/101894/An-Explosion-Prompts-Rethinking-of-Twitter-andFacebook.aspx.

Mastai, Judith. "There Is No Such Thing as A Visitor." In Museums After Modernism: Strategies of Engagement, edited by Griselda Pollock and Joyce Zemans, 173-177. Oxford: Blackwell Publishing, 2007.

May 25, 2011. http://support.twitter.com/entries/13920-frequently-askedquestions.

Mengel, Amy. "Social Media Smackdown: Tacome Art Museum vs. Cincinnati Art Museum," Social Media Today. August 26, 2009, Accessed June 10, 2011, http://socialmediatoday.com/index.php?q=SMC/119396.

New Museum. "George Condo: Mental States." Accessed June 22, 2011. http://www.newmuseum.org/quotes/?recent\#reactions.

New Museum. "Mission Statement." Accessed June 22, 2011. http://www.newmuseum.org/about/mission_statement/. 
Nerenberg, Jenara. "'Ask a Curator" Makes Museum Twitter Feeds Fun Again." Fast Company. August 31, 2010.

http://www.fastcompany.com/1686047/global-ask-a-curator-event-ontwitter-tempts-social-media-shy-museum-types.

Penner, Carolyn. "\#numbers." TwitterBlog (blog). March 14, 2011. http://blog.twitter.com/2011/03/numbers.html.

Pollock, Griselda and Joyce Zemans, ed., Museums After Modernism: Strategies of Engagement. Oxford: Blackwell Publishing, 2007.

Pollock, Griselda. "Un-Framing the Modern: Critical Space/Public Possibility." In Museums After Modernism: Strategies of Engagement, edited by Griselda Pollock and Joyce Zemans, 1-39. Oxford: Blackwell Publishing, 2007.

Powell, Juliette. 33 Million People in the Room: How to Create, Influence, and Run a Successful Business with Social Networking. Upper Saddle River: Pearson Education, Inc., 2009.

Preston, Jennifer. "Speaking Digitally About Exhibits." The New York Times (March 16, 2011), Section F26, http://www.nytimes.com/2011/03/17/arts/design/ speaking-digitally-aboutexhibits.html.

PRNewsWire. "Innovative New Campaign for George Condo Exhibit at the New Museum Brings Together New York Times and New York Tweets," PRNewsWire. March 23, 2011, Accessed June 10, http://www.prnewswire.com/news-releases/droga5-reinvents-art-criticismin-the-age-of-social-media-118504949.html.

Richarson, Jim. "Creating A Social Networking Plan." Museum Next (blog). July 4, 2009. http://www.museumnext.org/2010/blog/creating-a-social-media-plan.

Richarson, Jim. "Survey-Museums on Twitter." Museum Next (blog). May 3, 2011. http://www.museumnext.org/2010/blog/research-museums-on-twitter.

Richarson, Jim. "Twitter For Museums." Museum Next (blog). October 29, 2010. http://www.museumnext.org/2010/blog/twitter-for-museums.

Siemens, George. "Connectivism: A Learning Theory for the Digital Age," September 12, 2004, Accessed June 10, 2011, http://www.elearnspace.org/articles/connectivism.htm. 
Simon, N. "What is Twitter, Really? And Can It Do Anything For Museums?" Museum 2.0 (blog), April 16, 2008. http://museumtwo.blogspot.com/2007/04/what-is-twitter-really-and-can-itdo.html.

Tepper, Steven J. and Bill Ivey. Engaging Art: The Next Great Transformation of America's Cultural Life. New York: Routledge, 2008.

Thomas, Selma and Phyllis Hecht, ed., The Digital Museum: $A$ Think Guide.

Washington DC: American Association of Museums, 2007.

Tweet Beep. "About Tweet Beep." Accessed July 5, 2011. http://tweetbeep.com/about.html.

Tweet Deck. "About Tweet Deck." Accessed July 5, 2011. http://www.tweetdeck.com/about/.

Tweet Grader. "About Tweet Grader." Accessed July 5, 2011. http://tweet.grader.com/.

Twitter. "@21chotels." Accessed June 1, 2011. http://twitter.com/21chotels

Twitter. “@amnh.” Accessed June 1, 2011. http://twitter.com/amnh.

Twitter. “@ARTSHOTEL.” Accessed June 1, 2011. http://twitter.com/artshotel.

Twitter. “@AskACurator." Accessed June 1, 2011. http://twitter.com/AskACurator

Twitter. “@brooklynmuseum.” Accessed June 1, 2011. http://twitter.com/Brooklynmuseum.

Twitter. "@ cincyartmuseum." Accessed June 1, 2011. http://twitter.com/cincyartmuseum.

Twitter. “@metmuseum.” Accessed June 1, 2011. http://twitter.com/metmuseum.

Twitter. “@newmuseum.” Accessed June 1, 2011. http://twitter.com/newmuseum.

Twitter. "Frequently Asked Questions." Accessed June 1, 2011. http://twitter.com/frequentlyaskedquestions.

Twitter. "Twitter Business: Advertiser Analytics." Accessed July 5, 2011. http://business.twitter.com/advertise/analytics.

Twitter Counter. "About Twitter Counter." Accessed July 5, 2011. http://twittercounter.com/pages/about?ref=footer. 
Vogel, Carol. "Four to Follow." The New York Times (March 16, 2011), Section F24. http://www.nytimes.com/2011/03/17/arts/design/four-innovating-formuseums-online.html.

Vogel, Carol. "The Spirit of Sharing." The New York Times (March 16, 2011), Section F1, http://www.nytimes.com/2011/03/17/arts/design/museumspursue-engagement-with-social-media.html.

Wachnicki, Annie. E-mail message to Marketing Manager, New Museum, March 17, 2011

Weil, Stephen. "Rethinking the Museum: An Emerging New Paradigm." In Reinventing the Museum: Historical and Contemporary Perspectives on the Paradigm Shift, edited by Gail Anderson, 74-80. Oxford: AltaMira Press, 2004.

Zhang, Wei. "Reanimating Cultural Heritage Through Digital Technologies." Doctoral thesis, The University of Sussex, Brighton, England, 2008. 


\title{
CURRICULUM VITAE
}

NAME: $\quad$ Cara Christine Lyons

ADDRESS: Hite Art Institute/Department of Fine Arts 104 Schneider Hall University of Louisville Louisville, KY 40292

DOB: $\quad$ St. Louis, Missouri - July 25, 1987

\author{
EDUCATION \\ \& TRAINING: $\quad$ B.A. Arts Administration \\ University of Kentucky \\ 2006-2010
}

